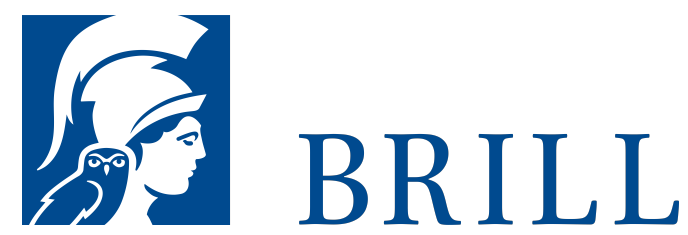

\title{
Die Länder des Islam
}

Geschichte, Tradition und der Einbruch der Moderne

Author: Arnold Hottinger

Arnold Hottinger, langjähriger Nahostkorrespondent der Neuen Zürcher Zeitung, berichtet seit Jahrzehnten über die islamische Welt. Er ist international hoch geachtet, als einer der ganz wenigen Journalisten, dessen tiefgründige Analysen auch von der Wissenschaft ernst genommen werden. Nach seinem großen Buch 'Islamische Welt' legt er nun ein neues wichtiges Werk vor. Darin beleuchtet und analysiert er die heutigen Probleme der Länder islamischer Religion und Kultur - vor dem Hintergrund ihrer vielfältigen unterschiedlichen Geschichte(n) und Besonderheiten und vor der Herausforderung durch die Moderne, mit der sie alle konfrontiert sind. Der engagierte Vermittler zwischen Orient und Okzident zeichnet ein vielschichtiges und differenziertes Bild der islamischen Welt, die, wie er überzeugend darstellt, mit dem Islam, schon gar nicht mit dem Islamismus, längst nicht hinreichend erklärt und zu verstehen ist, und er verdeutlicht die Strukturprobleme, die die Invasion der Moderne für diese Welt nach sich zieht.

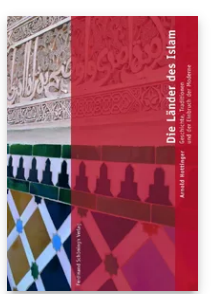

Pages: 368

Seiten

Language:

German

Subjects: Global History, History

Publisher: Brill | Schöningh

Hardback

Publication date: 19 Mar 2008

ISBN: $978-3^{-}$ 506-76541-3 List price USD $\$ 63.00$ 
For more information see brill.com

Order information: Order online at brill.com +44330 333 0049 | customerservices@brill.com Submission information: brill.com/authors

Titles published by Brill | Fink, Brill | mentis or Brill | Schöningh: +49(o)715413279216| brill@brocom.de 